UDC: $(316.3+791.43): 811 \quad$ https://doi.org/10.22190/JTESAP1801043K

\title{
CONTROVERSY IN THE CLASSROOM: THE CASE OF TRAINSPOTTING
}

\author{
Milena Kaličanin \\ University of Niš, Faculty of Philosophy, Serbia \\ Phone: 0641507872,E-Mail: mkostic76@gmail.com
}

\begin{abstract}
Since learning a language naturally entails the understanding of the cultural context in which it is used (Kramsch, 1993), it goes without saying that cultural awareness will be best acquired when students immerse themselves in the country of the target culture (Istanto, 2008). The role of the teacher in nurturing cultural understanding is to "take on the role of culture educator and deliberately assist students with their process of cultural analysis" (Istanto, 2009: 280). One of the ways to teach culture has definitely been to ask students to watch films from the target culture. This paper deals with the classroom experiment of teaching "Trainspotting". The students were divided into two groups with the task of presenting and interpreting different aspects of the film for the sake of enhancing classroom communication, as well as introducing the prevalent concerns of contemporary Scottish society. The first (linguistic) group had to report on the usage of the authentic Scots in the film paying special attention to its title - to investigate the root and meaning of the word "trainspotting", and the second (cultural) group had quite a demanding task of discussing the issues of urban Scottish youth culture. Though dealing with rather controversial themes, the practical case of teaching Trainspotting, based primarily on the interactive and communicative way of learning, definitely illustrates "how film can be used in an innovative way for teaching the target language and culture" (Istanto, 2008:290).
\end{abstract}

Key words: target language, target culture, interaction, communication, Scots, Trainspotting

\section{INTRODUCTORY REMARKS}

Since learning a language naturally entails the understanding of the cultural context in which it is used (Kramsch, 1993), it goes without saying that cultural awareness will be best acquired when students immerse themselves in the country of the target culture (Istanto, 2008). The role of the teacher in nurturing cultural understanding is to "take on the role of culture educator and deliberately assist students with their process of cultural analysis" (Istanto, 2009: 280). One of the ways to teach culture is to ask students to watch films from the target culture.

Using film as a learning tool does not represent an innovative approach to studying foreign culture and/or language. Lately, language teachers, as well as university professors, have been using this method of learning for various reasons. To name just a few: 1 . students' motivation is of paramount importance for the acquisition of a second culture 
and/or language, and film as a motivator makes the learning process more appealing and amusing; 2. film represents a valuable source of authentic language, as well as diverse genuine cultural contexts that enable students to comprehend the real-life situations they are usually not exposed to; 3 . students acquire knowledge by focusing on language exchanges simultaneously combined with visual clues (such as facial expressions and gestures), and; 4 . film extends the range of teaching techniques and resources by offering the opportunity for role-playing, class debates and discussions, retelling and summarizing, etc.

By watching films, the students' comprehension of the target culture is undoubtedly improved since a range of diverse interests (historical, philosophical, linguistic, psychological, sociological, geographical, architectural) can literally be found in any film. It is not a coincidence then that in his study "Film and Television in Education", Robert Watson (1990: 3) states: "The culture provided by all the mass media, but particularly by film and television, represents the most significant environmental factor that teachers have to take into account". In the same vein, Peter D. Groves (1996), in his book "Film in Higher Education and Research" claims that as a modern mechanical aid of learning, film represents a modern technology-based means of expression, and a valuable "instrument for research" (Istanto, 2009: 281).

Bearing all these ideas in mind, it is only logical to conclude that film should unquestionably be used in the classroom for the sake of motivating students to study by making their lessons more entertaining, as well as nurturing their understanding of the target culture.

\section{CONTEMPORARY SCOTTISH CULTURE: TRAINSPOTTING?}

Though film has generally proved to be a substantial and valuable learning tool, teachers of foreign language and culture primarily face difficulties in the process of film selection. Sometimes it may happen that the chosen film does not really represent the target culture or, better to say, does not always represent it in flying colours: it may be filled with various instances of colloquialisms and jargon (including a plethora of obscenities) belonging to a typical informal and non-standard style of expression, so that students may not instantly discern the far-reaching goals of the teacher's lesson plan.

An adequate illustration of the previous claim is definitely a highly popular Scottish film from the 1990s, Trainspotting, that has recently witnessed its second sequel. At first glance, the students are delighted with the idea of softening the strict rules of classroom conduct by indulging in controversial themes from Trainspotting, a film that strikingly offers a poignant cross-section of contemporary urban Scottish society. However, though immensely favoured by a world-wide audience and film critics, it still poses problematic issues to be dealt with in the classroom (theme-wise: youth culture and system of values, lack of proper idols and true heroes, heroin addiction, urban poverty and alienation, recurrently high unemployment rates, pessimism and hopelessness; language-wise: the usage of authentic Scots - rather interesting from diverse linguistic aspects, but extremely difficult for an average language student to be fundamentally comprehended in class).

As a lecturer in the field of Scottish Studies, I found myself on a rather bumpy road: how could I teach modern Scottish culture without referring to the well-known 1996 blockbuster with students who mostly have stereotypical and high-flown images of Scotland in their mind (clans, bagpipes, tartans, romantic highlanders, etc.)? Trainspotting 
absolutely ruins idealized and idyllic versions of Scotland by offering a rather realistic and strikingly painful glimpse of urban Scottish issues. Regardless of this fact, the students were given an assignment to watch Trainspotting and then they were divided into two groups with the task of presenting and interpreting different aspects of the film for the sake of enhancing classroom communication, as well as introducing the prevalent concerns of contemporary Scottish society. Thus, the first (linguistic) group had to report on the usage of authentic Scots in the film paying special attention to its title - to investigate the root and meaning of the word "trainspotting", and the second (cultural) group had quite a demanding task of discussing the issues of urban Scottish youth culture. The students' division into these two groups was swiftly organized since it was conducted on a voluntary basis: those who preferred studying language chose the linguistic group and those who preferred studying literature and film chose the cultural group.

\section{THE RESEARCH OF THE LINGUISTIC GROUP}

The linguistic group started its research from the film's title. They were rather curious about the original meaning of "trainspotting" since this was a word not frequently mentioned, let alone used in various English teaching materials that they consulted. After conveying a brief survey in the classroom, whereby the other students were asked to express their opinion on the meaning of "trainspotting", the linguistic group provided the rest of the class with its Oxford Dictionary explanation that defined "trainspotting" as the hobby of collecting the numbers and names of locomotives seen at railway stations and other vantage points (in frequent usage from 1959, chiefly in British English, in reference to the hobby of recording the numbers of the locomotives one has observed). It goes without saying that this survey was a good communication exercise since the answers offered (generally false) were rather humorous, the most humorous one being the fabricated analogy between bird-watching and trainspotting as examples of relaxing, but rather peculiar British hobbies from the perspective of the Serbian students of English language and literature.

Apart from the title's original dictionary meaning, the linguistic group referred to the colloquial meaning of trainspotting, crucial for the overall comprehension of the film. Thus, an insightful parallel between the official and slang definition of the film's title was successfully established. The students were provided with some help by the film's leading actor, Ewan McGregor, who, in one of his numerous interviews, explained the title as an example of British slang for shooting up heroin:

Heroin users use their mainline along their arms and inject up and down on the main vein. They call it 'Station to Station'. After enough intravenous injections the vein begins to collapse and turn a dark purple colour that's visible through the skin. British slang calls these 'train tracks'. Drug user must keep track of these veins hence the name Trainspotters. (McGregor, 1996)

Bearing in mind its colloquial explanation, the term finally refers to a session that leaves a dark linear mark (known as a "track") at the site of the affected vein. Hardcore users will tend to have multiple sites of injection and will locate, or "spot" an optimum vein - one with minimal "tracks" and discomfort or infection. A hit can be analogous to the impact of a locomotive or train. 
Though cruelly realistic, this explanation provided a good basis for the clarification of the film's language, which caused numerous troubles to the majority of the students who watched it without English or Serbian subtitles. Again, a brief survey was conducted prior to introducing the theme of the film's language. As expected, the majority of the students admitted that, at first, they could not understand what the main protagonist Renton was talking about. This was rather discouraging from the perspective of their vocation since the prevalent opinion was that the students of English language and literature could at least watch the film in the target language without subtitles. Trainspotting proved them incapable of such an endeavour.

The linguistic group then provided the class with some interesting facts: directed by Danny Boyle in 1996, based on a 1993 cult novel by Irvine Welsh, this black comedy crime drama film located mostly in Leith, Edinburgh, revolves around a group of young heroin users in the late 1980s. In order to portray the local characteristics of this Scottish area, and being a proud Scot himself, Welsh mostly used Scots in his novel, a practice later thoroughly employed by Boyle in the film. This fact created a suitable ground for the clarification of the origin and present status of the Scots language as one of the most specific features of contemporary Scottish culture.

The linguistic group conducted a detailed study on the Scots language and these are some of their findings (of course, combined with some insights and facts provided by me as their supervisor): spoken mostly in Lowland Scotland, Scots belongs to the German language group and has been generally mentioned in terms of frequent linguistic disputes alluding to its ambiguous status. On the one hand, there is a powerful linguistic faction that perceives Scots as one of the ancient varieties (dialects) of English, with its own distinct dialects and, on the other, there is a linguistic faction, equally potent as the former, that treats Scots as a distinct Germanic language. According to the Dictionary of the Older Scottish Tongue, prominent scholars of the Scots language, James Murray, William Craigie and A. J. Aitken, emphasized the limited range of uses of Scots today and its geographical linkage to the dialects of the north of England, so they fervently opposed the idea of having language status for Scots. Aitken was perhaps the most prominent critic of Scots of them all since he passionately claimed that the possible language status for Scots would basically mean "the institutionalization of shame" (Aitken, 1979: 85). However, the linguists David Murison and J. Derrick McClure, although taking into account the continuous historical dependence of Scots and English, emphasized Scots' specificity and dissimilarity in relation to the dominant neighbouring language. They even made a proposition for Scots to be treated as a minority European language and thus contributed to creating a new range of scholars interested in extending its forms of expression by translation from and to other languages (DOST, vol. 12: xxxvi).

Apart from this dichotomy, linguists in general have been reluctant to use the term Scots, being afraid of introducing nationalist issues in their work, especially if they have been Scottish themselves. However, all these confusions regarding the terminology and status of Scots officially ended in 2001, when the intention of the UK government to sign the European Charter for Regional and Minority Languages was finally ratified. Although Scots is listed under a section in the Charter that imposes no actual obligations on governments, its mere inclusion in this document (limited and belated for sure, but 
inclusion nevertheless) represents the official recognition of its language status, bearing in mind the fact that dialects are excluded from it. ${ }^{1}$

Though Trainspotting possibly offered the first encounter with the Scots language to the majority of the students in the classroom, it was certainly not the last. The students expressed their interest in this language and, apart from merely listening to it in the film, desired to study it in its written form. Praiseworthily, the linguistic group was prepared for this step and presented the students with some excerpts from Welsh's book. A worksheet with selected passages from the novel Trainspotting was perceived as a sort of a voluntary homework research assignment for the interested students; and the final recommendation on the part of the linguistic group was to read the whole book and compare it with the film so that each student could formulate a personal opinion on his/her preferred version of Trainspotting.

\section{THE RESEARCH OF THE CULTURAL GROUP}

The cultural group had quite a challenging task of representing and analyzing the major themes from the film. Since the film is based on the life of Renton, a young man deeply immersed in the world of drugs who tries to clean up and get out, despite the harmful influence of his friends, mostly heroin addicts as well, the valid decision of the cultural group was to make a provisional selection of Renton's monologues from the film and thus present the film's key subjects. They started with the main protagonist's wellknown statement - "Never let your friends tie you to the tracks" (Trainspotting 1996) thus suggesting Renton's secret desire to find a way to escape the vicious circle of heroin addiction and start leading an ordinary, uneventful, predictable life.

However, the great gap between Renton's secret desire and its final realization was immediately presented in class by quoting the monologue on how and why he started and persisted with the habit of injecting heroin. From Renton's perspective, the first associations that the majority of people have regarding the theme of heroin addiction misery, despair, death, illness - could not be compared with the mere pleasure of injecting heroin:

When you're off it you are suddenly obliged to worry about all sorts of other shite. Got no money: can't get pissed. Got money: drinking too much. Can't get a bird: no chance of a ride. Got a bird: too much hassle. You have to worry about bills, about food, about some football team that never fucking wins, about human relationships and all the things that really don't matter when you've got a sincere and truthful junk habit. (Trainspotting 1996)

The cultural group claimed that it was precisely this painstaking sincerity describing the cruel reality of an unemployed drug addict with no optimistic prospects for the future that contributed to the cult status of the film, since it was ranked $10^{\text {th }}$ by the British Film Institute in its list of Top 100 British films of all time. Also, in 2004, it was voted the best Scottish film in a general public poll.

\footnotetext{
${ }^{1}$ See also Kostić, Use of Scots in Institutional Discourse: Examples from the Poetry of MacDiarmid, Leonard, Lochhead and Morgan (Filozofski fakultet Niš, 2015, pp. 193-204).
} 
Apart from the monologues dealing with the reality bites of heroin addiction, the cultural group found the monologue that spoke about the burning issue of the Scottish nation nowadays, especially from the perspective of the unsuccessful Independence Referendum (2014) $)^{2}$ and Brexit (2016) ${ }^{3}$. In this particular monologue, Renton's vivid outburst at the naïve suggestion of one of his friends that being Scottish inevitably involves a great amount of national pride is potently captured:

It's SHITE being Scottish! We're the lowest of the low. The scum of the fucking Earth! The most wretched, miserable, servile, pathetic trash that was ever shat into civilization. Some people hate the English. I don't. They're just wankers. We, on the other hand, are colonized by wankers. Can't even find a decent culture to be colonized by. We're ruled by effete arseholes. It's a SHITE state of affairs to be in, Tommy, and all the fresh air in the world won't make any fucking difference! (Trainspotting 1996)

This monologue alludes to the long-lasting Scottish/English animosity starting with the English invasion of Scotland in the late $13^{\text {th }}$ and early $14^{\text {th }}$ centuries' Wars of Scottish Independence, continuing with a generally undesirable Act of Union with England in 1707 and Scotland's final merging into the United Kingdom in 1801. In the 1979 Referendum, the majority of the Scottish population voted against devolution; exactly twenty years later, in another Referendum, devolution was finally achieved. This enabled the creation of the Scottish Parliament in Edinburgh at the beginning of the new millennium, thus announcing a new chapter in Scottish/English relations. Fortunately, the cultural group could not avoid providing the class with some historical data, which was, though only in sketches, presented to the point and rather effectively and greatly contributed to the students' comprehension of the film.

The film starts with Renton's catchy monologue about the futility of the modern, alienated lifestyle based on the alleged survival steps prescribed to each individual in advance. This sort of life involves a constant rat race, whereby the fulfilment of a goal inevitably leads to another level of the race, thus making an individual incapable of ending it, ultimately finding him/herself in a constant state of hurry and exasperation, with the fear of inevitable failure. Renton chooses not to "choose life", but heroin instead, since the prescribed life is not much different from his addiction:

Choose life. Choose a job. Choose a career. Choose a family. Choose a fucking big television, Choose washing machines, cars, compact disc players, and electrical tin can openers. Choose good health, low cholesterol and dental insurance. Choose fixedinterest mortgage repayments. Choose a starter home. Choose your friends. Choose leisure wear and matching luggage. Choose a three piece suite on hire purchase in a

\footnotetext{
${ }^{2}$ The Scottish Independence Referendum took place on September 18, 2014. The referendum question was 'Should Scotland be an independent country?" to which voters answered with 'yes' or 'no'. The majority of the voters voted against independence with 55.25 percent of the votes, and in favor of the independence 44.65 percent voted according to a report by the $\mathrm{BBC}$ after the referendum.

${ }^{3}$ Brexit - a Referendum in the United Kingdom held in June, 2016. People of the UK voted whether they should leave or remain in the European Union. Leave won by $52 \%$ to $48 \%$. This result caused slight turbulence in Scotland. There was an opinion poll there, to which the majority of 62 percent of Scots voted in favor of the UK staying in the EU. Scottish first Minister Nicola Sturgeon declared that a new independence referendum was possible because it was, in her opinion, democratically unacceptable that Scotland should be taken out of the EU against its will.
} 
range of fucking fabrics. Choose DIY and wondering who the fuck you are on a Sunday morning. Choose sitting on that couch watching mind-numbing spirit-crushing game shows, stuffing fucking junk food into your mouth. Choose rotting away at the end of it all, pishing your last in a miserable home, nothing more than an embarrassment to the selfish, fucked-up brats you have spawned to replace yourself. Choose your future. Choose life ... But why would I want to do a thing like that? I chose not to choose life: I chose something else. And the reasons? There are no reasons. Who needs reasons when you've got heroin? (Trainspotting 1996)

However, Renton instinctively feels that he should ultimately change his selfdestructive lifestyle. He decides to start his life anew, far away from his friends, far away from Edinburgh - he captures the stolen money from his partners in crime and thinks he is ready to start from scratch:

But, that's gonna change - I'm going to change. This is the last of that sort of thing. Now I'm cleaning up and I'm moving on, going straight and choosing life. I'm looking forward to it already. I'm gonna be just like you. The job, the family, the fucking big television. The washing machine, the car, the compact disc and electric tin opener, good health, low cholesterol, dental insurance, mortgage, starter home, leisure wear, luggage, three piece suite, DIY, game shows, junk food, children, walks in the park, nine to five, good at golf, washing the car, choice of sweaters, family Christmas, indexed pension, tax exemption, clearing gutters, getting by, looking ahead, the day you die. (Trainspotting 1996)

The cultural group was on a quest to find out whether Renton's life took a different turn, so they passionately watched Trainspotting 2 (2017) - although this was out of the scope of their class assignment - just to find the following answer:

Choose life, choose Facebook, Twitter, Instagram and hope that someone somewhere cares. Choose looking up old flames, wishing you'd done it all differently. And choose watching history repeat itself. Choose your future, choose reality TV, slut shaming, revenge porn. Choose a zero hour contract, a two hour journey to work. And choose the same for your kids, only worse, and smother the pain with an unknown dose of an unknown drug made in somebody's kitchen. And then... take a deep breath. You're an addict, so be addicted. Just be addicted to something else. Choose the ones you love. Choose your future. Choose life. (Trainspotting 2017)

After comparing and contrasting Renton's "choose life" monologues from the first and second part of Trainspotting, the cultural group also presented a rather interesting analogy between Renton's rejection of post-modern hedonism and Erich Fromm's criticism of radical hedonism. Starting from a dilemma - to have or to be? - Fromm concedes that there is nothing wrong in determining happiness as the source of life; what is wrong is the definition of happiness as the satisfaction of any desire or subjective need a person may feel (radical hedonism), since, defined in that incomplete way, in contemporary society, based on the existential mode of having rather than being, it does not lead to harmony and peace but to egotism, selfishness and greed. As a consequence of people being conditioned to have only selfish and possessive desires, there appears an atrophy of emotional life: we become alienated both from ourselves and other human beings. Acts of cruelty take place not because people are driven by innate aggression, but because they no longer have or feel any emotional bond to other people. The way out, 
according to Fromm, of this state of "constant disequilibrium" is to achieve the unity of fully developed human reason and love. By becoming fully human, "man will arrive at the experience of oneness... - oneness within man, oneness between man and nature, and oneness between man and other man" (Fromm, 1977: 314). In this manner, modern man might transcend his narcissistic position and "escape the hell of self-centredness and hence self-imprisonment" (Fromm, 1977: 315). ${ }^{4}$

Although the idea of experiencing the state of oneness as the way out from the traps of modern civilization is perceived as valid and legitimate in Fromm's opinion, Renton could not entirely acknowledge it. A pessimistic idea that he cherishes is that there is no escape from addiction, it can just be altered in terms of terminology - the mere fact that we are born into this world makes us addicts. However, (and this is a point that makes him closer to Fromm), if you can choose addiction, then choose to be addicted to the ones you love. Only in this case, the cultural group concluded with a slight dose of optimism, would your life restore its initial meaning. After watching and analyzing both sequels, this is how the cultural group comprehended the film's main message. Estimably, the cultural group gave an additional task to the rest of the class - to watch the second sequel - and then to finally come to a point of agreement or disagreement with the ultimate conclusion that this group of students had made.

Finally, after the presentation by the cultural group, the class was divided into two factions: the first found the film's conclusion utterly pessimistic, whereas the second found a dose of hope and optimism in the second sequel of the film and thus in the life of Renton as a synonym for an everyman, a lost postmodern individual craving for personal redemption. The fact which is important from the methodological point of view is that all the students were actively engaged in class, they all wanted to participate in the appealing class topic and discuss personal critical views with each other. So, though there are basically no right answers to the questions raised in the cultural group's presentation, the mere fact that it caused such an enthusiastic response on the part of the students in the classroom testifies to its methodical quality and significance.

\section{CONCLUSION}

Bearing in mind the classroom experiment of teaching Trainspotting, it can be concluded that films definitely represent an effective platform for the students to be immersed in the culture of the target community. As Istanto (2009: 288-89) summarized, the film can broaden the geographical knowledge about the target country, give exposure to the sociolinguistic issues, socio-economics and socio-political situations and also educational issues in the target country. It can furnish the background knowledge about the target culture, facilitate effective learning and also provide strong motivation for

\footnotetext{
${ }^{4}$ The cultural group found that from a severe drug addict, Renton became a fervent critic of the postmodern lifestyle for its emotional atrophy and consumerism. He perceives that the condition of modern man is that of a willing spiritual addiction, and thus enters the group of modern artists (Rich being just one of them) depicting and protesting against this gloomy fact:

We see daily that our lives are terrible and little, without continuity, buyable and saleable at any moment, mere blips on a screen, that this is the way we live now... We become stoical; we hibernate; we numb ourselves with chemicals; we emigrate internally into fictions of past and future; we thirst for guns... (Rich, 1993: 20)
} 
students to learn the target language and culture because students can learn in more interesting ways than traditional class activities. Though dealing with rather controversial themes (particularly for a class discussion), the practical case of teaching Trainspotting, based on the interactive and communicative way of learning, can definitely illustrate "how film can be used in an innovative way for teaching the target language and culture" (Istanto, 2009:290).

\section{REFERENCES}

Aitken, A. J. Scottish Speech: A Historical View with Special Reference to the Standard English of Scotland. In Languages of Scotland, ed. A. J. Aitken and Tom McArthur, Edinburgh: Edinburgh University Press, 1979, pp. 85-118.

Dictionary of the Older Scottish Tongue. http://www.dsl.ac.uk/. (Accessed October 5, 2017).

Fromm, Erich. The Anatomy of Human Destructiveness. Middlesex, England: Penguin Books, 1977.

Groves, P.D. Film in Higher Education and Research. Proceedings of a Conference Held at the College of Advanced Technology, Birmingham in September 1964. Birmingham: Pergamon Press, 1996.

Istanto, J.W. Language Immersion Programme as an Avenue to Nurture Cultural Awareness and Accelerate Students' Language Proficiency. In W.M. Chan, K.N. Chin, M. Nagami \& T. Suthiwan, Process and Process-Orientation in Foreign Language Teaching and Learning (pp. 173-192), Singapore: Centre for Language Studies, National University of Singapore, 2008.

Istanto, J. W. "The Use of Films as an Innovative Way to Enhance Language Learning and Cultural Understanding". Electronic Journal of Foreign Language Teaching 2009, Vol. 6, Suppl. 1, pp. 278-290.

Kostić, Milena. "Use of Scots in Institutional Discourse: Examples from the Poetry of MacDiarmid, Leonard, Lochhead and Morgan”. Jezik, književnost, diskurs. Filozofski fakultet Niš, 2015, pp. 193-204.

Kramsch, C. Context and Culture in Language Teaching. London: Oxford University Press, 1993.

McGregor, Ewan. Trainspotting. https://scotmedia08.wikispaces.com/Trainspotting, 1996. (Accessed June 10, 2017).

Rich, Adrianne. What is Found There: Notebooks on Poetry and Politics. New York: Virago Press, 1993.

Trainspotting. https://en.wikiquote.org/wiki/Trainspotting_(film), 1996. (Accessed October 6, 2017).

Trainspotting 2. http://www.nme.com/blogs/nme-blogs/trainspotting-2-modern-updatechoose-life-monologue-1819855\#CSvrhUyUULyWLtyW.99, 2017. (Accessed October 6, 2017). 